\title{
THE CONTOURS OF PARTY PATRONAGE IN ARGENTINA
}

\author{
Gerardo Scherlis \\ Universidad de Buenos Aires and Consejo Nacional \\ de Investigaciones Científicas y Técnicas (CONICET)
}

\begin{abstract}
Studies on the Argentine public administration have usually underlined the weakness of Argentine state bureaucracies. On the basis of these assertions, scholars have tended to equate the number of state jobs with cases of patronage. By doing so, they have neglected the crucial issue of the scope of appointments effectively controlled by political parties. This article applies an innovative empirical inquiry to measure the extent of party patronage, assessing where, how deeply, and to what extent parties reach into the Argentine federal state structures. While the results by and large confirm the widespread notion of the broad scope of political appointments in Argentina, they refute the conventional hypothesis of a state thoroughly colonized by parties. Overall, the results suggest that parties' distribution of public jobs in the Argentine federal state is oriented less to mass-style patronage than to gaining effective and broad control over state institutions.
\end{abstract}

Studies of the Argentine public administration have usually underlined the weakness, lack of autonomy, high politicization, and low performance of Argentine state bureaucracies (Oszlak 1999; Spiller and Tommasi 2007). The notion of a professional civil service has been recently characterized as a "very precarious idea" in light of contemporary Argentine history (Ferraro 2006). On the basis of these assertions, political scientists have tended to equate the number of state jobs with cases of party patronage, assuming the total control of parties over all state agencies. Consequently, a good number of studies have referred to the extent of patronage by using the number of public employees or figures of public spending on personnel as proxy measures for patronage. By doing so, they have neglected the crucial issue of the actual scope of appointments effectively controlled by political parties. Scholars of Argentine party politics have also emphasized the importance of patronage in the functioning of the main parties (Levitsky 2007; Leiras 2007), but they have failed to produce systematic research on the actual ability of political parties to reach into state structures. The broad consensus on the importance of patronage politics in the functioning of Argentine parties and in the low performance of the public bureaucracies suggests the relevance of assessing the actual extent and workings of this practice.

In this article I apply an innovative empirical inquiry to measure party patronage in the Argentine federal state. With this approach I try to assess where, how deeply, and to what extent parties reach into state structures to control the

I am grateful to Peter Mair for his inspiration, guidance, and support. I also wish to thank the three anonymous $L A R R$ reviewers for their insightful comments and suggestions.

Latin American Research Review, Vol. 48, No. 3. (c) 2013 by the Latin American Studies Association. 


\section{Latin American Research Review}

allocation of jobs. The results of the research by and large confirm the widespread notion of the broad reach of political appointments in Argentina. However, they refute the conventional hypothesis of a state thoroughly colonized by parties. In fact, I show that while political parties appoint almost all senior positions, their role as appointer decreases as we move down the bureaucratic hierarchy, and there are substantial differences in the extent of party patronage across areas of the Argentine federal state.

While the bulk of the empirical analysis focuses on the extent of party patronage, the results also shed light on the workings and rationale of this practice. Overall, I contend that parties in Argentina lack the operative capacity to control appointments outside of the highest echelons of the federal bureaucracy and that they generally have no strategic interest in appointing below this level. Accordingly, the results suggest that parties' distribution of jobs in the Argentine federal state is less oriented to traditional mass-style patronage than toward gaining effective control over state institutions.

In the first section I define the concept of party patronage and discuss the relationship between the extent and the rationale of party patronage in contemporary democracies. The second section reviews previous contributions to the measuring of patronage and puts forward the approach and methodology followed in this research. I present my findings on the actual extent of party patronage in the Argentine federal state in the third section. The fourth section points out the main explanatory factors accounting for the results.

\section{PARTY PATRONAGE}

I follow Kopecký, Scherlis, and Spirova (2008) in defining party patronage as the power of a party to appoint people to positions in public life in a discretionary manner. The key feature of this definition is that it limits patronage to the discretionary allocation of state positions by party politicians, irrespective of the characteristics of the appointee, the legal status of the decision, or the balance of power between the parts. This definition does not imply that party patronage necessarily excludes merit as a criterion for personnel selection, nor does it imply that appointees are exclusively party members or party voters. A party may decide to appoint people on the basis of their skills, or to appoint people without previous linkages with the ruling party, or both. Rather, this definition suggests that patronage appointments are made "without any encumbrance in terms of due process or transparency" (Flinders 2009, 550) or, in other words, that politicians have discretion to choose the criterion they consider fit to fill state positions.

Party patronage is not defined by a specific goal and, in fact, may serve a variety of different ends. Patronage may certainly work as a clientelistic exchange for political allegiance. But patronage may also very well pursue several specific goals. Strengthening the party organization by entrenching party networks within the state, forging intraparty agreements, overseeing the implementation of the party platform, or taking over state institutions to put them in the service of the ruling party are some of the reasons that parties allocate state jobs (Sorauf 1959; Müller 2006). 


\section{Parties as the Active Subject of Party Patronage}

A troublesome side of this definition of party patronage refers to the active subject of the action. When is it appropriate to say that the discretionary allocation of state jobs is indeed party patronage? Naturally, official decisions about state appointments are not taken by parties as such but by state officials. I am interested not in who signs the nomination decrees but in whether party politicians are in reality involved in the nomination processes. The point is that in practice not every discretionary allocation of state positions is necessarily a case of party patronage. Party patronage means that the responsibility for the appointments lies with parties or party politicians more generally. I consider that party patronage exists whenever the responsibility for the appointment lies with a party politician or with someone appointed by and responsible to a party politician. Paraphrasing Richard Katz $(1986,43)$ and his first requisite for party government, I consider patronage to be party patronage when decisions about appointments are effectively taken by people chosen in elections conducted along party lines, or by individuals appointed by and responsible to such people. While this definition might usher in a variety of border cases, especially in political systems with loosely institutionalized parties, it has the advantage of allowing inquiry into the presence of other modes of patronage that may take place in state government. In fact, state structures usually are conflictive arenas in which actors apart from partiessuch as bureaucrats, unions, and corporate sectors-play the games of patronage.

In sum, party patronage can be seen as a distinct phenomenon. It is defined mainly by the subject of the action (the party or party politicians) and the practice of allocating public jobs in a discretionary manner.

\section{Party Organizations and Patronage}

Party patronage has been traditionally understood as a particularistic exchange between politicians and citizens. Probably the most influential theory on the development of this type of patronage politics is that of Shefter (1977). Shefter points to the timing of enfranchisement relative to the consolidation of a professional and autonomous state bureaucracy to assess whether or not parties resort to patronage to mobilize a popular base. Shefter's main contention is, in short, that if an independent bureaucracy is established and consolidated before party competition enfranchises male universal suffrage, politicians will not have at their disposal the state structure to build their parties and capture electoral clienteles. In contrast, if the timing is the opposite and mass democracy exists prior to the inception of autonomous state bureaucracies, parties will resort to state jobs as a means to recruit and mobilize political allegiance.

However, the conventional belief that parties are always eager and prepared to make mass use of public jobs to mobilize political support is challenged by recent developments in the fields of party organization and public administration. Current research in these fields suggests that parties may nowadays lack the capability as well as the interest to extensively use public jobs as a payoff and are more interested in securing loyal and often competent management of state offices (Pe- 
ters and Pierre 2004; Kopecký and Mair 2012; Jalali, Silva, and Moreira 2012). In this regard, evidence from both established and new democracies consistently shows two intertwined phenomena. On the one hand, experts see a pronounced process of interpenetration between party organizations and state structures, to the point that parties are increasingly defined as semi-state organizations or public utilities (Katz and Mair 1995; Biezen 2004). On the other hand, studies show that mainstream parties' membership is in decline, but that these parties no longer perceive a strong membership as necessary. Consequently, they very rarely endeavor to develop mass organizations (Dalton and Wattenberg 2002; Webb and White 2007; Whiteley 2011). The combination of these processes indicates that parties may be paying less heed to the use of patronage as a means to reward legions of activists. Instead, politicians may be using patronage to secure control over state infrastructure while they shore up their parties as networks of officeholders. ${ }^{1}$ Rather than a means to sustain large networks of support, patronage then becomes a mode of government (Kopecký and Mair 2012).

This change in the rationale behind party patronage should have strong implications for its extent. In short, if this change takes place we should expect parties to focus mainly on the state's top-level positions, while lower-level jobs are mostly left outside their domain.

\section{OPERATIONALIZING AND MEASURING PARTY PATRONAGE}

Recent studies about the size of patronage in Argentina have attempted to tackle this issue by using measures as proxies. Scholars have measured patronage as the expenditures allocated to personnel spending by the national (Gordin 2002) or provincial (Remmer 2007) governments, or as the overall figure for public employment of provincial governments (Calvo and Murillo 2004; Kemahlioglu 2011). The underlying assumption of these studies is that because Argentina lacks a stable civil service, every state job or every state salary involves party patronage. Subsequently, variations in the number of public jobs or in public spending in salaries are equated with variations in the levels of patronage.

The problem with these proxies is that they do not reflect the real extent of patronage practices because they measure different aspects of employment in the state administration. They focus on how many people are employed or how much money is spent in salaries, figures that say very little about the ability of parties to appoint. Actually, figures on public employment or public spending in personnel may be deceptive indicators to measure personnel turnover and appointments in general (Orlansky 2009).

A more refined account of this subject is provided by Ferraro (2006). Ferraro measures the proportion of temporary personnel compared to permanent personnel covered by civil service regulations to judge the extent of political appoint-

1. The control of state institutions does not refer uniquely to steering the course of public policies. As Ingrid van Biezen notes, the increasing interdependence between parties and states "creates incentives for parties to make unauthorized use of public assets and to extract state resources through public office-holding positions" (2004, 717). 
ments in the Argentine federal state. Yet, the problem with this classification is that it assumes that all temporary employees are politically appointed and all those permanent employees covered by civil service regulations are not, an assumption that does not account for the real practices in the Argentine public administration. As I explain later in more detail, the distinction between permanent or temporary personnel cannot be equated with political or nonpolitical appointees.

\section{The Extent of Patronage: Range, Depth, and Proportion}

I propose to gauge the actual extent of party patronage, trying to assess where and how deeply parties reach into state structures to control the allocation of jobs. ${ }^{2}$ The extent of patronage is measured along three different dimensions: range, depth, and proportion. First, I establish the range of these practices, answering whether patronage is evenly spread across the whole state apparatus or if, in contrast, parties appoint more in certain areas of government than in others. I also want to find out how deeply parties reach into state structures. In this regard, I try to establish whether, in different areas, parties nominate and control only senior ranks of government, if they also appoint midlevel positions, or if they reach down to the bottom level of technical and service personnel. The third variable assesses the extent of party patronage in reference to its relative amount. Parties might appoint employees at three levels in two sectors but still in very different proportions. It makes a difference whether parties appoint only a few, most, or all the employees in a specific area.

\section{Designing the Empirical Inquiry}

As the first step in operationalizing the concept of patronage, I designed a model of the Argentine state that makes it susceptible to cross-country comparison. I followed Peters's (1988) suggestion to compare public administrations according to different policy areas. For comparative purposes, I divide the state into the following eight policy areas: culture and education, economy, finance, foreign affairs, judiciary, media, military and police, and welfare. The use of policy areas as the first criterion of distinction permits an in-depth observation of patronage practices and is based on the hypothesis that parties appoint on different scales in different areas. This might shed light on variations and nuances overlooked so far by studies on this field, which take the state as a monolithic entity.

As a second step I further subdivide each policy area by different types of institutions. In so doing I expand the analysis beyond the core of the civil service, which has been the usual object of studies on patronage and public administration but that encompasses barely 7 percent of federal employment in Argentina. In addition, if every policy area is expected to present different traits, so are different institutional types. Public administration normally includes institutions involved in delivering services or in the production of goods, such as state-run 
media, schools, courts, hospitals, state-owned companies, and so on. In Argentina these types of institutions, which I label executive institutions (EI), include 82 percent of public employees, control important budgets, and perform significant functions, all of which make them worthy of attention that they have not received so far with regard to appointments. Last, the contemporary literature on public administration stresses the importance of new forms of governance in which power is delegated from the core executive to an increasing number of regulatory agencies and other nondepartmental institutions that are responsible for the formulation, implementation, and regulation of public policy (Peters and Pierre 2004, 6). Since this process has also been noted in reference to Latin America (Jordana and Ramió 2010), it is to be expected that parties and politicians will try to exert influence on the form and composition of these bodies. Consequently, I include in my generic model of the state three different types of institutions: ministerial departments (MD), nondepartmental agencies and commissions (or decentralized agencies, DA), ${ }^{3}$ and executive institutions (EI). Each one of the eight policy areas of the Argentine federal state is in turn subdivided into these three institutional types, except the judiciary, which is treated as having only executive institutions. ${ }^{4}$

\section{Mapping Out the Practice of Patronage}

Having defined the policy areas and their institutional representations, I take each group of institutions within each policy area to be the unit of analysis at this stage. Interviews with key informants are the main source used to examine the actual situation of patronage. The bulk of the data stems from forty (five per each area) face-to-face semistructured interviews with people familiar with patronage practices in the different policy areas. Interviewees included senior and midlevel bureaucrats, ${ }^{5}$ experts in public administration, NGO workers, journalists, and union leaders. These key informants are asked about the range, depth, and proportion of patronage in the different areas. Results are presented on a range from 0 to 1 , where 0 is a policy area completely free of patronage and 1 is a policy area in which all or almost all of the appointments of employees of all the three institutional types from the top to the bottom level are discretionary appointments made by parties.

The questionnaire includes an additional open-ended question, requesting from the interviewees additional comments and potential explanations for the answers on the extent of party patronage. This question seeks to find out about the rationale and the workings of party patronage. ${ }^{6}$

3. Because in Argentina most of these institutions are known as decentralized agencies I use that term interchangeably with nondepartmental agencies and commissions.

4. Appendix 1 includes examples of institutions of every policy area and institutional type.

5. This included seven governmental administrators (hereinafter AGs), members of the Cuerpo de Administradores Gubernamentales. This is an elite bureaucratic corps created in 1984 that currently has about 170 members serving in diverse management or advisory positions in different areas of the federal state.

6. Appendix 2 shows the model of the survey questionnaire utilized in the interviews. 


\section{THE EXTENT OF PARTY PATRONAGE IN ARGENTINA}

By 2008 approximately 600,000 people were employed by the Argentine national (or federal) state. Figures of public employment had shown very slight fluctuations between 1960 and 1989, oscillating between 850,000 and 1.1 million employees (Orlansky 1989). Over the course of the next decade, the size of the national state shrank strikingly due to fiscal adjustment, privatization of public companies, and decentralization policies (Oszlak 2003). ${ }^{7}$ The figures of public employment remained stable for a few years and showed a tendency to grow starting in 2003. ${ }^{8}$

The results of the interviews show that, irrespective of the number of employees, none of the eight policy areas of the Argentine federal state is free from the reach of parties. Nonetheless, as table 1 shows, parties reach different areas, institutional types, and levels of the state differently.

Four findings stand out. First, parties appoint almost all senior state positions, using the opportunities provided by the law and circumventing the restrictions imposed by the legal system when they consider it necessary. Second, parties appoint more in ministries than in decentralized and executive agencies. Third, although parties reach all state areas, the extent of patronage varies substantially across them. And fourth, parties are far from having a monopoly over appointments in the Argentine state.

Additionally, the answers reveal that the power of politicians to appoint fundamentally aims at taking control of the state apparatus, in order to both dominate policy-making processes and control the resources involved in these processes.

\section{Parties Appoint Almost All Senior Positions}

Parties appoint all senior positions in almost all state institutions, including ministries, decentralized agencies, and executive institutions of all areas. In most cases, nominations at the top level are established by law. In some others, politicians circumvent legal regulations to appoint.

In accordance with the law, parties appoint all superior political authorities in the ministries (by 2007, 11 ministers, 48 secretaries, and 89 undersecretaries), and their respective cabinets of advisors, almost all directors and presidents of 82 decentralized agencies and commissions, the judges of the Supreme Court (whenever there is a vacancy), the commandants of all armed forces, presidents and boards of publicly owned companies, and 25 ambassadors. ${ }^{9}$

Remarkably, parties bypass or circumvent legal constraints to appoint other top positions that are legally beyond their reach or, in strict terms, to which they have

7. The twenty-four Argentine provinces by 2008 had approximately 2.1 million employees, more than three times the number of the national state. Hence a thorough study of patronage in Argentina should integrate both national and subnational levels of government.

8. This growth is mainly due to the transfer of several companies from the private to the public sphere and the establishment of new public universities, but also to the moderate but consistent growth of the majority of state institutions.

9. The number of legally permitted political appointments of top positions might roughly be estimated at between 2,700 and 3,500, assuming, with Ferraro (2006), an average of five advisors per official. 
Table 1 Extent of party patronage per sector and institutional type

\begin{tabular}{lcccc}
\hline & $\begin{array}{c}\text { Ministerial } \\
\text { departments }\end{array}$ & $\begin{array}{c}\text { Decentralized } \\
\text { agencies }\end{array}$ & $\begin{array}{c}\text { Executive } \\
\text { institutions }\end{array}$ & $\begin{array}{c}\text { Mean by } \\
\text { sector }\end{array}$ \\
\hline Media & 1 & 0.82 & 0.93 & 0.92 \\
Welfare & 0.94 & 0.83 & 0.72 & 0.83 \\
Economy & 0.85 & 0.61 & 0.7 & 0.72 \\
Culture and education & 0.84 & 0.75 & 0.55 & 0.71 \\
Finance & 0.66 & 0.63 & 0.63 & 0.64 \\
Military and police & 0.73 & 0.6 & 0.55 & 0.63 \\
Foreign affairs & 0.76 & 0 & 0.4 & 0.39 \\
Judiciary & & & 0.33 & 0.33 \\
Mean by institutional type & 0.82 & 0.61 & 0.6 & 0.65 \\
\hline
\end{tabular}

Note: The figures express composite measures that result from the combination of values of the range, depth, and quantity of party patronage in eight different sectors and three different policy areas of the Argentine federal state.

restrained access. In most cases parties transform constrained powers into full powers through ad hoc devices of dubious legality. A case in point is the direction of the Broadcasting Commission (Comité Federal de Radiodifusión, COMFER), the agency responsible for regulating and monitoring the installation and functioning of television and radio stations. According to the regulation issued by the last military government, COMFER is run by a board comprising members of the three armed forces. Although the law was naturally seen as obsolete with the advent of democracy, none of the administrations since 1983 had attempted to change it as of 2010. Instead, alleging its inapplicability, presidents issued a decree by which they made a discretionary nomination of a delegate of the executive power to run the agency (who, in turn, controlled other appointments at the top of the agency). ${ }^{10}$ Something similar has occurred with the national TV station, Channel 7, which has always been run by a delegate of the executive power (interventor). Likewise, all presidents have claimed situations of emergency in order to directly appoint the board of the largest national health care agency, the institute of social services for pensioners (Programa de Atención Médica Integral, PAMI), sidestepping the legal proceedings that demand that affiliate representatives participate in constituting the board.

Remarkably, parties have circumvented the law to nominate senior positions at the regulatory agencies of public utilities (gas, electricity, communications, transport, etc.). These agencies must be run by boards selected by the executive power on the basis of previous examinations, and applicants are required to fulfill specific qualifications. Yet, once again, presidents have preferred to allege situations of exception and lack of time to undertake the selection process in order to cover these key positions by decree. For example, although law 24,076/1992 establishes that the members of the board of the gas regulatory agency, ENARGAS, must

10. Author's interview with a professor of social communication at University of Buenos Aires, Buenos Aires, August 2007. The law was finally changed in 2010. The appointment of the directors of the agency that replaced COMFER was among the most controversial issues of the new regulation. 
be experts in the area selected through examinations, during the first Kirchner administration the directors of the board were politicians closely related to the president and the minister of federal planning, and all were directly appointed by a presidential decree. ${ }^{11}$ When, in the wake of reliable allegations of corruption, the president of the board was forced to resign, President Kirchner issued another decree appointing another politician he trusted, even when the decision was openly criticized by the national media. ${ }^{12}$

Ruling parties also force and often bypass legal constraints to manipulate the appointment of judges, turning constrained powers into pure patronage powers. Lifetime tenure for Supreme Court justices has been repeatedly violated by different means (threats of impeachments have been historically common) and under different arguments in recent Argentine history (Helmke 2005). Legal constraints are more openly, albeit less visibly, circumvented when politicians manipulate results of open contests to select lower-court judges in order to pick their favorite candidates. Legally, the president is entitled to opt for the candidate he prefers from a list of three applicants submitted by the Council of Magistracy. This system provides politicians (the president or, more commonly, the minister of justice), with a limited degree of discretion. However, negotiations between political councillors and political pressures from the Ministry of Justice often end in grotesque manipulation of the composition of the threesomes. While that has been the case since the Council of Magistracy was established in 1999 (Roth 2007), evaluations have become particularly irregular since 2003. Irregularities especially involve appointments of those judges who deal with cases of corruption, drug trafficking, smuggling, and economic demands against the state. ${ }^{13}$

The determination of parties to appoint top-level positions all across the federal state, including those that are not legally available, responds to their decision to secure a strict compliance to presidential orders and a tight hold over state bureaucracies. A well-known journalist from the newspaper Página 12 summarizes the rationale behind these nominations: "Ministers, state secretaries, directors of decentralized agencies, presidents of state-owned companies, must all be soldiers who guarantee blind obedience; they must ensure that the agency they head will work in line with the political project led by the president."14

\section{Parties Appoint All across the State, but Ministries Are the Loci of Party Patronage}

As table 1 shows, parties have greater reach in ministerial departments than in the rest of the state. Parties reach all ministries and usually appoint top- and midlevel employees in all of them.

Every change of government entails a sweep of all top ministerial positions:

11. Detailed information about appointments at regulatory agencies was provided by the NGO ACIJ (Civic Association for Equality and Justice), Buenos Aires, August 2007. See also "Sin control en los entes reguladores," La Nación, February 19, 2007.

12. See "Investigación por coimas: Pese a las críticas, la designación sería por decreto," Clarín, May 18, 2007.

13. Author's interview with a Supreme Court official, Buenos Aires, July 2007.

14. Author's interview with a journalist from Página 12, Buenos Aires, September 2007. 


\section{Latin American Research Review}

ministers, secretaries, undersecretaries, and their respective cabinets of advisers. Most times, turnovers also entail the arrival of new midlevel officials. Actually, midlevel positions in the ministries, such as national directors or general directors, constitute a key zone that politicians strive to control, assuming that these functionaries will in turn form their own working teams responsive to them. In a context of unstable and transient bureaucracies, appointing personnel is how officeholders obtain the loyalty and responsiveness they demand. In that sense, "working with your own people" is the mode in which the administration regularly functions. ${ }^{15}$

The fact that many midlevel officials obtain tenure from within the framework of the civil service regulations is not a signal of apolitical appointments. Indeed, most times the civil service exams constitute a mere facade to regularize political appointments. Frequently new political authorities force the displacement of midlevel civil servants to replace them with new employees, who are then regularized through manipulated contests. When they cannot simply replace the national and general directors, political authorities may alternatively assign the real functions of management to political appointees, even when they hold temporary contracts, thus marginalizing the civil service staff, which is confined to insubstantial tasks (Minsky 2001).

It is worth noting that the functioning of most ministries is based on the development of programs, a format that emerged at the beginning of the 1990s as a new method to organize ministerial bureaucracies. Instead of working with permanent bureaucracies, programs are created to achieve specific targets for which they require specialized personnel. The notion of programs as a new strategy for public administration was inspired by the school of new public management and was theoretically supported and many times financed by multinational organizations (such as the Inter-American Development Bank, the World Bank, and the United Nations Development Program) with the goal of providing more flexible and adaptable tools to attain specific policy goals (López and Zeller 2006). What indeed happens is that every time a new government assumes power, programs are replaced, and with them the managers and coordinators in charge. These programs provide political authorities with substantial room to contract new employees. ${ }^{16}$ By the mid-1990s there were more than sixty programs functioning in the orbit of the executive power, meaning that different rings of parallel bureaucracies had emerged in all ministries. The use of temporary jobs to hire new personnel gave rise to the massive presence of contratados, employees appointed through different contractual forms and for a fixed term. ${ }^{17}$

15. As an AG serving at the Ministry of Education put it: "That is the natural and accepted way to run the ministries. No functionary trusts people who were hired by his predecessor" (author's interview, August 2007).

16. A well-established practice consists of asking the appointee to bring two additional curriculum vitae, which must show lower qualifications than the one of the applicant. The trick is known by both the applicant and the employer and functions—as do so many other practices— to "cover formalities." Author's interview with a program coordinator at the Ministry of Social Development, July 2007.

17. The real number of contratados is not registered by any reliable source. Yet, it is clear that they outnumber the permanent staff in several ministries (Spiller and Tommasi 2007, 172-173). 
With regard to the scale of appointments at ministries, unlike what happens with senior and midlevel positions, the majority of the technical and service personnel are not replaced with every change of government. That is obviously the case with permanent personnel, whose positions are protected by law. But to a large extent, and in contrast to usual assumptions (for example Spiller and Tommasi 2007, 174), it also applies to the contratados. Although every time new authorities assume power in a ministry they might decide not to extend the job contracts of the temporary personnel, the majority of the contratados actually manage to survive turnovers. New authorities do bring some new people to undertake sensitive tasks and do not extend the contracts of those more obviously linked to the previous political authorities or clearly identified as activists. But in general, most of the contratados with bottom-level jobs are not replaced. Cases of massive replacements in an agency may still exist (especially in the welfare sector), but they are more the exception than the rule. In contrast, it is common that the contratados try to adapt to the new authorities, irrespective of how they were originally appointed. In that sense, even though many of them got their positions through a political connection, the large majority of personnel are much more concerned with keeping their jobs than with any party loyalty. ${ }^{18}$

Every few years groups of those employees who have been working as temporary personnel for some time are tenured through "exceptional" decrees enacted by the minister or by the chief of the ministerial cabinet. These passages to staff (pases a planta), as these measures are known in the jargon, are usually negotiated between the unions and office-holding politicians. ${ }^{19}$ Therefore, the clear-cut distinction between temporary personnel as politically appointed versus the permanent staff as apolitically appointed must not be overstated. In reality, since 1990 almost all employees have been hired first as temporary personnel in order to get permanent positions at some point (Bambaci, Spiller, and Tommasi 2007, 169-175). On that note, the successive incorporation of contratados along with the periodic passages to staff have produced the accumulation of recognizable "geological layers" of employees in every ministry, each layer having its origin in the period of a different political authority (Oszlak 1994; Dalbosco 2003).

Parties also appoint in decentralized agencies. There are even a few DAs colonized by parties, particularly in the welfare area. However, a good number of DAs (especially in areas such as security, finance, economy, and foreign affairs) have more autonomous and stable bureaucracies than the ministries. To take an example from the area of economy, while some departments of the Ministry of Economy, such as the Secretariat of Commerce or the Secretariat of Industry, are highly politicized, many of the DAs in the same area enjoy a higher degree of professionalization.

Executive institutions appear, albeit by a very slight margin, to be the least open to patronage of our three institutional types. Parties do not appoint at the bottom level of security agencies (police and armed forces), embassies, and courts.

18. Author's interviews with AGs serving at the Ministries of Education and Foreign Affairs, Buenos Aires, August and October 2007.

19. Author's interview with a leader of a public employees' union, September 2007. 


\section{Latin American Research Review}

However, the difference between executive institutions and the other institutional types does not hinge so much on the range or depth of the appointments but rather on the relatively low proportion of patronage registered in these institutions. In effect, in addition to the cases of security, foreign affairs, and the judiciary, parties appoint only some (up to one third) of the bottom-level positions in financial, economic, and educational and cultural executive agencies.

Overall, recent assumptions in the literature about the displacement of the practice of patronage from ministerial departments do not apply to the Argentine state. Surely because ministries are still the locus where most substantial policies are decided, parties appoint at the core of the administration more than they do in other institutional types. Instead, as a political scientist who served in the Ministry of Interior explained, "the further you get from the minister, the more chances you have to find lower levels of politicization." ${ }^{20}$ Yet, disparities across institutional types are less significant than those across policy areas.

\section{Parties Reach Differently in Different Sectors}

Parties do not reach all policy sectors equally. In fact, the data highlights the existence of substantial differences from one sector to another. As shown by the aggregate figures in table 1, media is at the top of the list. This sector exhibits very feeble bureaucracies in its ministerial departments, regulatory agency, and executive institutions. Welfare stands out as another patronage-ridden sector. In particular, the Ministry of Social Development and the decentralized agencies in its orbit are known for their weak, unstable, and politicized bureaucracies.

At the other extreme, the judiciary and foreign affairs appear to be the areas least permeable to party patronage. Parties do not participate in the appointment of bottom- and midlevel personnel in the courts, which, as far as the nomination of personnel is concerned, function as an autonomous branch of state. That autonomy accounts for the low rate of patronage in the sector despite the decisive role of parties in the appointment of judges. Parties do reach the different levels of the Ministry of Foreign Affairs, although this is the only ministry in which most mid- and bottom-level positions are occupied by members of a professional bureaucracy, the diplomatic corps. Additionally, presidents have consistently abided by the legal limitation of twenty-five political ambassadors. ${ }^{21}$ The absence of party patronage in its sole decentralized agency, the National Commission on Space Activities (CONAE), probably renders an exaggeratedly low figure for the whole sector. ${ }^{22}$ Yet, foreign affairs are generally acknowledged to be the most professionalized area of the Argentine state.

Security and finance also exhibit comparatively low figures of party patronage.

20. Author's interview, August 2007.

21. Author's interview with an ambassador and professor of constitutional law at the University of Buenos Aires, Buenos Aires, July 2007.

22. CONAE is a small agency that has kept the same director and managers since its creation in 1994. In the words of an employee who has worked there for all this time, "it is an agency that does not bother the government and in which the government is not interested." Author's interview, Buenos Aires, September 2007. 
The case of security is mainly explained by the existence of professional military and police forces, with their specific regimes for the recruitment of personnel. Finance stands out as the most even sector, with relatively strong bureaucracies in all three institutional types. Parties do appoint senior positions in this sector as much as they do in any other, but in this case a financial techno-bureaucracy prevents politicians from reaching most mid- and bottom-level positions. As Geddes $(1994,14)$ suggests, the implementation of reforms that bring bureaucratic competency to previously patronage-ridden agencies depends on whether those reforms can serve the immediate political interests of the politicians who have the power to initiate them. The administration of the financial sector demands a degree of expertise that cannot be found in the ranks of Argentine party organizations (Camou 2007). Because this area is crucial for the fate of any government, parties have decided to accept a strategy of professionalization of the sector, prioritizing good performance over particularistic rent seeking. ${ }^{23}$

Last, economy combines some highly politicized ministerial departments, quite professionalized decentralized agencies, and state-owned companies in which patronage is high but, as explained below, parties are not the main patrons, hardly reaching beyond top positions.

Certainly, the autonomy of state agencies in every area is ultimately contingent on parties' strategic decisions, as has been proved in recent years by the case of the National Institute of Statistics (INDEC). The government decided to take over this long-standing autonomous and prestigious institution in order to manipulate inflation data to appear more favorable than real figures (largely by altering the composition of the consumer price index or CPI). ${ }^{24}$ The conflict began in the last trimester of 2006, when a section head refused to submit confidential information on her work on the CPI to the secretary of commerce. The secretary of commerce, backed by the president, replaced that midlevel official with an employee from the Ministry of Economy without any background in the INDEC. This measure triggered a series of forced resignations in the agency (first, the immediate superior of the replaced employee, shortly afterwards the director of the institution, and eventually more than twenty qualified functionaries). Many of the INDEC employees protested the political intervention, but the institution was soon occupied by dozens of new employees who deferred to the secretary of commerce. ${ }^{25}$ In sum, the president decided to reach deep into a highly professionalized institution as soon as it determined that the goal-in this case to control the official statistics-was worth the intervention. The case of INDEC proves that no public agency in Argentina is safe from political intervention. Yet, it also exposes the existence of institutions that have achieved high standards of professionalization and have managed to maintain their professional staffs throughout different administrations.

By contrast, partisan appointments are common in areas such as media and

23. For the case of the deliberate professionalization of the tax collection agency in the early 1990s (then called Dirección General Impositiva, DGI), see Eaton 2003. According to Eaton, "A Peronist majority in Congress shared with the President the view that improving tax collection was critical in the party's attempt to defend fiscal stability and win elections" $(2003,58)$.

24. "Cristina's Challenges," Economist, October 26, 2007. See also Levitsky and Murillo (2008, 25).

25. See “Denuncian que el INDEC está totalmente desmantelado," La Nación, January 14, 2008. 


\section{Latin American Research Review}

welfare. These areas have traditionally been subject to party patronage, and their politicization is taken for granted by both their employees and the public. The need to professionalize them was never seriously considered nor is it seen as electorally convenient. Institutions such as the Ministry of Social Development and the public media have always served parties' political goals, in one case as a source of clientelism, in the other as an instrument for propaganda, and parties never perceived the need (nor were they forced) to professionalize their bureaucracies.

\section{Patronage Is Not Monopoly of Parties}

There are a variety of alternative ways to get a state position other than being appointed by a party politician. Some decentralized agencies and executive institutions have their own meritocratic systems for the recruitment of personnel, which work in a reasonably professional way. In agencies from different policy areas, such as the taxation agency AFIP, the Central Bank, the National Commission on Atomic Energy, the National Institute of Industrial Technology, and the National Commission on Scientific and Technological Research, among others, personnel are recruited according to previously established competitive procedures. A few of them, in the terms of Spiller and Tommasi $(2008,103)$, are "islands of bureaucratic excellence."

However, it is remarkable that lower figures of party patronage do not always indicate transparent and merit-based personnel selection processes. In many cases, those figures reflect the presence of other actors that dominate the distribution of patronage, sharing that role with party politicians or even displacing them as the main appointers. It can be argued that the absence of professional state bureaucracies only partially brings about party patronage. Trade unions are decisive patronage players, especially at the lower levels, in many ministries, in media institutions such as public television, and in state-owned companies. It is important to note that the unions of state personnel operate as corporatist entities with their own specific interests, appointing their people and pushing for their agendas, with autonomy from political parties. ${ }^{26}$ Judges dominate the process of personnel recruitment in the judiciary with large degrees of discretion. In the case of the Federal Police, recruitments and promotions are subject to frequent discretionary decisions of the chief officers, without any involvement of party politicians (Gorgal 2002). In addition, some techno-bureaucracies have managed to control midlevel positions at some institutions and in practice recruit the technical personnel. One case is that of the association of financial experts (Asociación Argentina de Presupuesto, ASAP), which has a strong influence in financial ministerial departments. The National Commission of University Evaluation (in the orbit of the Ministry of Education) is another example of an institution controlled by a techno-bureaucracy. ${ }^{27}$

The same midlevel bureaucrats quite often gain autonomy from political au-

26. Author's interview with a leader of a public employees' union, Buenos Aires, September 2007.

27. Author's interview with a researcher from the NGO CIPPEC, Buenos Aires, September 2007. 
thorities to form their working teams. Typically, general directors and coordinators in less professionalized ministries-such as education, justice, labor, or health-recruit the employees who work in their programs without the involvement of their superior political authorities. The (discretionary) appointments decided by these coordinators and directors, themselves frequently recruited on nonpartisan grounds, can hardly be deemed as cases of party patronage.

Another significant proportion of state jobs are appointed via nepotism, in which party politicians have no direct involvement. Children and relatives of employees have priority-actual, if not legal-to get jobs in most state institutions, especially in state-owned companies. The appointment of friends and acquaintances of employees are widespread practices as well. Whenever a state agency is searching for personnel, it is quite common for the employees to bring their relatives and friends to fill these vacancies, though usually experience and qualifications are taken into some consideration..$^{28}$

In formal terms every appointment can be attributed to the ruling party, since it must eventually be ratified by an authority appointed by someone elected along party lines (the chief of the ministerial cabinet, a minister, a director of a decentralized agency, a president of a state-owned company, etc.). Yet, when assessing the actual extent of party patronage it seems important to see who actually recruits the personnel and decides appointments. In that sense, actors other than parties take part in the allocation of state jobs. Many times this is due to the existence of other patrons competing for the colonization of state agencies. But in most cases the main reason is parties' lack of operative capacity and lack of political determination to cover all the positions at their disposal.

\section{EXTENT AND RATIONALE OF PARTY PATRONAGE}

It is doubtless that "the Argentine state lacks bureaucratic autonomy" (Levitsky 2007, 213), and that "the absence of civil service rules allows the discretionary use of public employment" (Calvo and Murillo 2004, 744). In that context, party patronage is in all probability the most significant mode by which bureaucratic autonomy is impeded and public employment is distributed on a discretionary basis, involving all the most senior positions, a majority of midlevel ministerial positions, and many midlevel positions at decentralized agencies. The ruling party, and in particular the presidents, make the major decisions on appointments across the administration, especially at senior levels. In line with Shefter's (1977) explanation of the different developments of patronage in Western countries, it is arguable that when democracy was initiated in Argentina (1912-1916), and the same when it was restored in 1983, parties found it easy to take advantage of the fragility of weak state bureaucracies to employ their own followers. Parties did not then face a strong constituency for bureaucratic autonomy, nor did they find the incentives that, according to Geddes, might have led them to promote the professionalization of state bureaucracies. 


\section{Latin American Research Review}

However, it is clearly wrong to view the president or parties in general as responsible for most appointments in all areas and institutions of the Argentine state. In fact, of all state jobs that are periodically created, the vast majority are filled with no direct participation of party politicians. As shown above, parties do fill almost all senior positions by discretionary appointments, but their role in appointments declines once we look at lower-level positions. The reach of parties is higher in some policy areas than in others, and parties are only one among various actors that can recruit and appoint public employees on a discretionary basis.

Rather than by any legal restriction, this relatively limited role of parties is explained by four main factors. First, revisiting Shefter's approach, although state bureaucracies are not autonomous and professionalized in general, there are a few agencies with a long tradition of bureaucratic autonomy. Parties can still take over these agencies if they see fit, as the INDEC case unmistakably shows. Yet bureaucratic autonomy is generally respected unless a deliberate political decision has been taken to do otherwise. Second, parties did find it electorally convenient to professionalize a few areas and agencies. As Geddes (1994) notes, securing good management of certain areas may be seen by politicians as strategically convenient, even when they must resign patronage powers. This has been the case with financial institutions. Parties have maintained political control over the agencies through the appointment of the most senior positions, but they have accepted the professionalization of the area. Third, in the field of state structures there are powerful corporatist entities that successfully withstand partisan encroachment and compete with parties as important appointers in different areas (typically, but not only, trade unions).

Fourth, the most decisive factor is that current party leaders at the national level lack the organizational capability as well as the interest to reach down to the bottom of many state agencies. Results confirm that current political leaders have an utmost interest in appointing senior positions, even when not legally allowed or when they have to sidestep legal regulations. In contrast, they are much less interested in the bottom ranks of the administration. Appointing top-level positions-as well as some key midlevel positions-seeks the control of state agencies, which naturally implies determining policy but simultaneously involves access to the partisan management of state resources. In other words, controlling key nominations not only aims at overseeing policy-making processes but also operates as a precondition for allocating resources of different kinds, such as subsidies, public works, and investments, all of which have huge political relevance. In contrast, the distribution of bottom-level jobs has no political significance and, accordingly, is not a common strategy at the federal state..$^{29}$

Additionally, elected presidents lack a pool of loyal and qualified party cadres at their disposal from which to staff the federal administration. They also need not deal with intense pressure from a rank and file hungry for jobs, a demand that

29. Author's interview with an expert in public administration at University of Buenos Aires, Buenos Aires, October 2007. This interviewee distinguishes the federal state from provincial governments, in which the distribution of jobs as a particularistic exchange to broaden partisan clienteles seems to be a common practice. 
is mostly confined to subnational levels of government. This leads party politicians to resort to nonpartisan networks to fill a good number of key positions, on the one hand, and, on the other, to delegate patronage powers to nonpartisan actors. ${ }^{30}$ Indeed, politicians delegate to midlevel officeholders recruitment for a large share of state positions that they could in principle appoint directly. That is why, below the highest levels of government, appointments are rarely linked to any party membership. ${ }^{31}$ Officials search for people they can trust and who in many cases have the necessary skills. What they look for can be described, in the words of Aberbach and Rockman (1994), as "responsive competence," for which the party might not be the most appropriate or even a possible source. In this context, a large number of appointments are decided on the basis of personal linkages. Relatives, friends, university colleagues, and professionals who are former coworkers from think tanks, NGOs, and corporations are all potential appointees for mid- and bottom-level jobs.

\section{CONCLUDING REMARKS}

Historically, partisan appointments in Argentina have been associated with mass patronage (Rock 2005). This might remain true for provincial and municipal stages. However, the findings of this study suggest that, in line with processes identified in other settings (see Kopecký, Mair, and Spirova 2012), Argentine parties use patronage in the federal state mainly as a mode of government. Patronage in its most traditional sense certainly does exist and in some areas is still a common pattern. Yet whether the ruling parties are interested in implementing a particular set of policies or in using public positions for rent seeking-or a combination of the two-the overall primary goal of partisan appointments is to dominate state institutions.

The understanding of the politics of appointments and the relationships between party organizations and state structures, in Argentina and in Latin America in general, is still in its initial stages. Much more comparative research is needed to discover what games are really being played in this field. What motivates parties to appoint, what criteria they follow to select the appointees, and what kind of linkages exist between ruling parties and nonpartisan appointees emerge as relevant questions that should be part of a research agenda along with the issue of the extent of patronage. With this article I hope to have contributed by suggesting an approach that improves substantially on the measures developed thus far and that is easily replicable in other settings, and by using this approach to gauge the actual extent of patronage and connect it to the analysis of the rationale of patronage in Argentina.

30. According to an official serving at the Public Employment Office, "President Duhalde was hardly able to reach up to undersecretaries with his own people; and Kirchner had much less than that. He had a little provincial bureaucracy which had been ruling the province of Santa Cruz; so he had to recruit from other places and rely on other people's recruitment." Author's interview, Buenos Aires, June 2007.

31. A professor of public administration at Universidad de San Andrés asserts: "From undersecretaries downward, whom everyone appoints has little to do with a party and much more with acquaintances and networks of affinities." Author's interview, Buenos Aires, July 2007. 


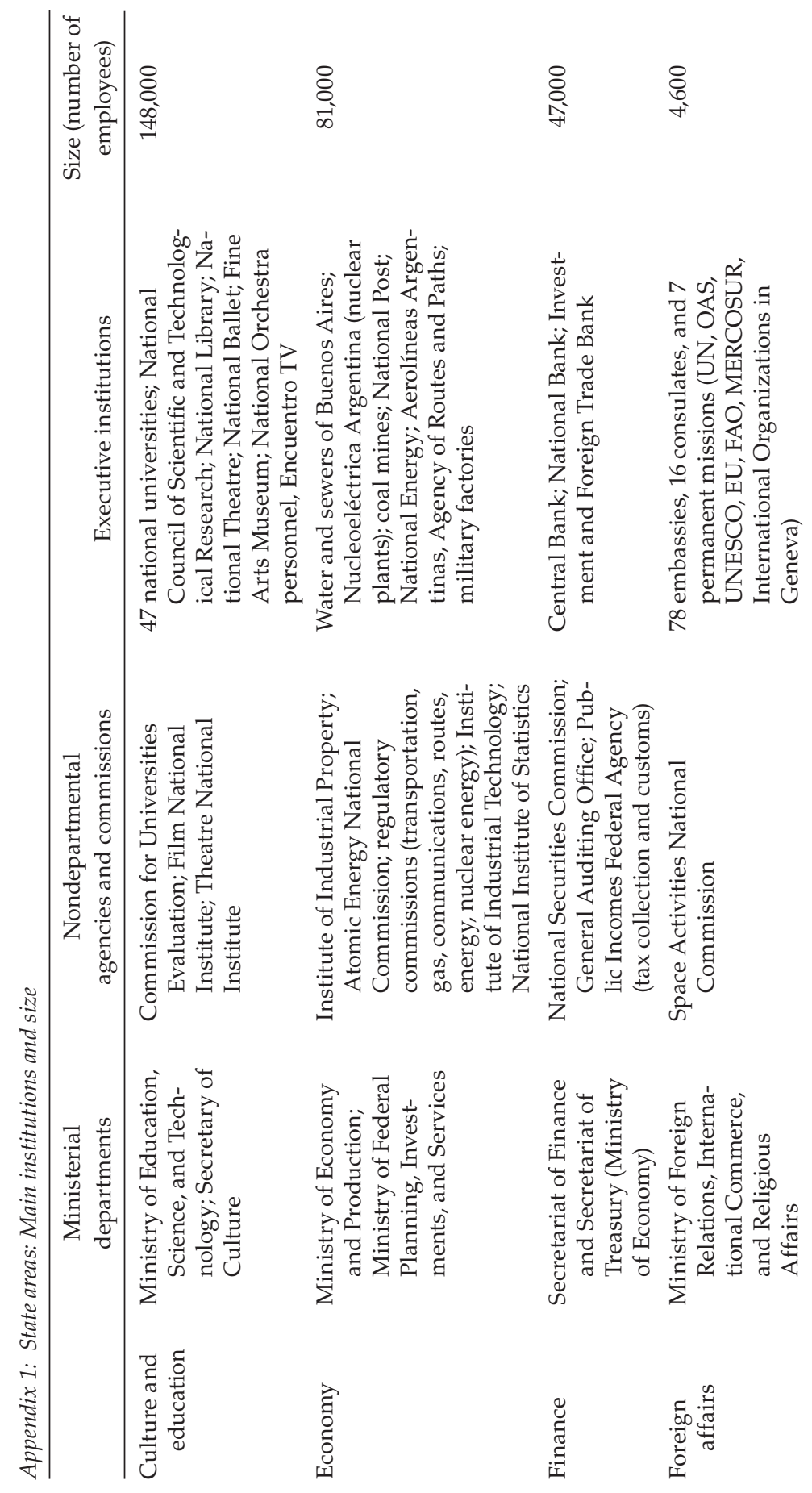




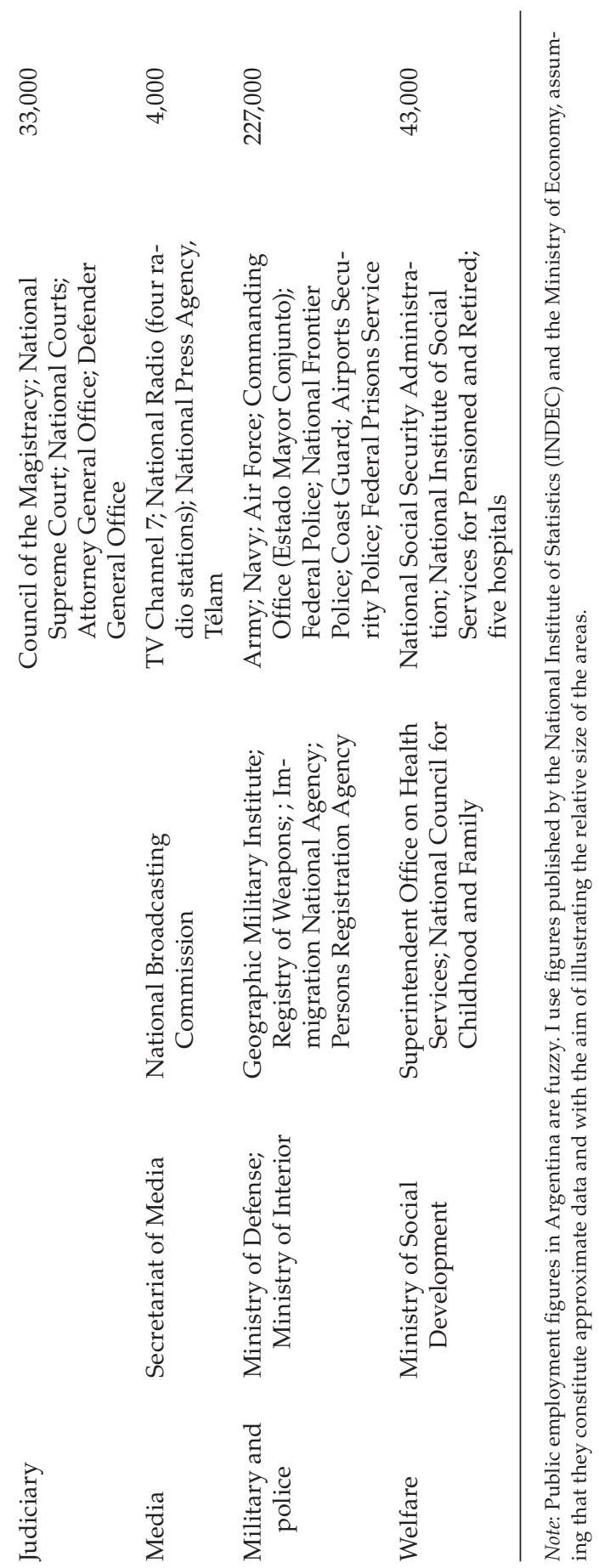


Appendix 2: Expert survey questionnaire

Q1. In your opinion, political parties appoint positions

1. in a few institutions

2. in most institutions

3. in all institutions

Q2. In your opinion, political parties appoint positions at

1. the top managerial level

2. the middle-level employees

3. the bottom-level technical and service personnel

Q3. In your opinion, political parties appoint

1. up to one-third of the positions of the area

2. between one-third and two-thirds of the positions

3. more than two-thirds of the positions

Q4. Additional comments, questions, and clarifications; potential explanations for the scope and extent of party patronage [open-ended question].

\section{REFERENCES}

Aberbach, Joel D., and Bert A. Rockman

1994 "Civil Servants and Policymakers: Neutral or Responsive Competence?" Governance 7 (4): 461-469.

Bambaci, Juliana, Pablo Spiller, and Mariano Tommasi

2007 "The Bureaucracy." In Pablo T. Spiller and Mariano Tommasi, The Institutional Foundations of Public Policy in Argentina, 151-181. Cambridge: Cambridge University Press.

Biezen, Ingrid van

2004 "Political Parties as Public Utilities." Party Politics 10 (6): 701-722.

Calvo, Ernesto, and Maria Victoria Murillo

2004 "Who Delivers? Partisan Clients in the Argentine Electoral Market." American Journal of Political Science 48 (4): 742-757.

Camou, Antonio

2007 "El saber detrás del trono: Intelectuales-expertos, tanques de pensamiento y políticas económicas en la Argentina democrática 1985-2001." In Think Tanks y políticas públicas en Latinoamérica, edited by Adolfo Garcé and Gerardo Uña, 139-176. Buenos Aires: Prometeo.

Dalbosco, Hugo Luis

2003 "Crisis de representatividad y burocracia en la Argentina." Colección, no. 14: 99-123.

Dalton, Russell J., and Martin P. Wattenberg

2002 Parties without Partisans: Political Change in Advanced Industrial Democracies. Oxford: Oxford University Press.

Eaton, Kent

2003 "Can Politicians Control Bureaucrats? Applying Theories of Political Control to Argentina's Democracy." Latin American Politics and Society 45 (4): 33-62.

Ferraro, Agustín

2006 "Una idea muy precaria: El nuevo servicio civil y los viejos designados políticos en Argentina." Latin American Research Review 41 (2): 165-186.

Flinders, Matthew

2009 "The Politics of Patronage in the United Kingdom: Shrinking Reach and Diluted Permeation." Governance 22 (4): 547-570.

Geddes, Barbara

1994 Politician's Dilemma: Building State Capacity in Latin America. Berkeley: University of California Press. 
Gordin, Jorge

2002 "The Political and Partisan Determinants of Patronage in Latin America, 1960-1994:

Gorgal, Diego A Comparative Perspective." European Journal of Political Research 41 (4): 513-549.

2002 "Estado y seguridad: Apuntes para una reformulación del sistema de seguridad interior en la Argentina." Colección, no. 13:281-369.

Helmke, Gretchen

2005 Courts under Constraints: Judges, Generals, and Presidents in Argentina. Cambridge: Cambridge University Press.

Jalali, Carlos, Patricia Silva, and Diogo Moreira

2012 "Party Patronage in Portugal: Treading in Shallow Water." In Party Patronage and Party Government in European Democracies, edited by Petr Kopecký, Peter Mair, and Maria Spirova, chap. 15. Oxford: Oxford University Press.

Jordana, Jacint, and Carles Ramió

2010 "Delegation, Presidential Regimes, and Latin American Regulatory Agencies." Journal of Politics in Latin America 2 (1): 3-30.

Katz, Richard

1986 "Party Government: A Rationalistic Conception." In Visions and Realities of Party Government, edited by Francis G. Castles and Rudolf Wildenmann, 31-71. Berlin: De Gruyter.

Katz, Richard S., and Peter Mair

1995 "Changing Models of Party Organization and Party Democracy: The Emergence of the Cartel Party." Party Politics 1 (1): 5-28.

Kemahlioglu, Ozge

2011 "Jobs in Politicians' Backyards: Party Leadership Competition and Patronage." Journal of Theoretical Politics 23 (4): 480-509.

Kopecký, Petr, and Peter Mair

2012 "Patronage as an Organizational Resource." In Party Patronage and Party Government in European Democracies, edited by Petr Kopecký, Peter Mair, and Maria Spirova, 3-16. Oxford: Oxford University Press.

Kopecký, Petr, Peter Mair, and Maria Spirova, eds.

2012 Party Patronage and Party Government in European Democracies. Oxford: Oxford University Press.

Kopecký, Petr, Gerardo Scherlis, and Maria Spirova

2008 "Conceptualizing and Measuring Party Patronage." Working Paper 25, Committee on Concepts and Methods, International Political Science Association, September.

Leiras, Marcelo

2007 Todos los caballos del rey: La integración de los partidos políticos y el gobierno democrático de la Argentina, 1995-2003. Buenos Aires: Prometeo.

Levitsky, Steven

2007 "From Populism to Clientelism? The Transformation of Labor-Based Party Linkages in Latin America." In Patrons, Clients, and Policies: Patterns of Democratic Accountability and Political Competition, edited by Herbert Kitschelt and Steven Wilkinson, 206-226. Cambridge: Cambridge University Press.

Levitsky, Steven, and María Victoria Murillo

2008 "Argentina: From Kirchner to Kirchner." Journal of Democracy 19 (2): 16-30.

López, Andrea, and Norberto Zeller

2006 "La administración pública nacional en Argentina (1983-2001): El impacto de las reformas sobre su estructura y personal." Revista Argentina de Sociología 4 (6): 129-158.

Minsky, Rafael

2001 "Obstáculos para la profesionalización de la gestión pública." VI Congreso Internacional del Centro Latinoamericano de Administración para el Desarrollo (CLAD), Buenos Aires, November 5-9.

Müller, Wolfgang

2006 "Party Patronage and Party Colonization of the State." In Handbook of Party Politics, edited by Richard S. Katz and William J. Crotty, 189-195. London: Sage. 


\section{Latin American Research Review}

Orlansky, Dora

1989 "Empleo público y condiciones de trabajo: Argentina 1960-1986." Desarrollo Económico 29 (113): 63-86.

2009 “¿Validez de una demostración? Patronazgo y empleo público provincial." Desarrollo Económico 48 (192): 557-558.

Oszlak, Oscar

1994 "Estado y sociedad: Las nuevas fronteras." In El rediseño del Estado, edited by Bernardo Kliksberg, 45-78. Mexico City: Fondo de Cultura Económica.

1999 "The Argentine Civil Service: An Unfinished Search for Identity." Research in Public Administration 5:267-326.

2003 "El mito del estado mínimo: Una década de reforma estatal en Argentina." Desarrollo Económico 42 (168): 519-543.

Peters, B. Guy

1988 Comparing Public Bureaucracies: Problems of Theory and Method. Tuscaloosa: University of Alabama Press.

Peters, B. Guy, and Jon Pierre, eds.

2004 Politicization of the Civil Service in Comparative Perspective. London: Routledge.

Remmer, Karen L.

2007 "The Political Economy of Patronage: Expenditure Patterns in the Argentine Prov-

Rock, David inces, 1983-2003." Journal of Politics 69 (2): 363-377.

2005 "Argentina: A Hundred and Fifty Years of Democratic Praxis." Latin American Research Review 40: (2): 221-234.

Roth, Laura C.

2007 "Acerca de la independencia judicial en Argentina: La creación del Consejo de la Magistratura y su desempeño entre 1994 y 2006." Desarrollo Económico 47 (186): 285-318.

Shefter, Martin

1977 "Party and Patronage: Germany, England and Italy." Politics and Society 7:403-452.

Sorauf, Frank J.

1959 "Patronage and Party." Midwest Journal of Political Science 3 (2): 115-126.

Spiller, Pablo T., and Mariano Tommasi

2007 The Institutional Foundations of Public Policy in Argentina: A Transactions Cost Approach. Cambridge: Cambridge University Press.

2008 "Political Institutions, Policymaking Processes, and Policy Outcomes in Argentina." In Policymaking in Latin America: How Politics Shapes Policies, edited by Ernesto Stein and Mariano Tommasi, with Carlos Scartascini and Pablo Spiller, 69-110. Washington, DC: Inter-American Development Bank.

Webb, Paul, and Stephen White, eds.

2007 Party Politics in New Democracies. Oxford: Oxford University Press.

Whiteley, Paul

2011 "Is the Party Over? The Decline of Party Activism and Membership across the Democratic World." Party Politics 17 (1): 21-44. 